\title{
Tuberculosis Verrucosa Cutis with Bilateral Pulmonary Tuberculosis
}

\author{
Tina Wardhani, Adhi Djuanda, Sri Adi Sularsito
}

\begin{abstract}
Abstrak
Seorang laki-laki berusia 28 sejak 16 tahun lalu menderita bintil kecil, keras, kasar, dan tidak nyeri pada punggung kaki kanan. Dalam 2 tahun ini kelainan kulit menjadi tebal serta meluas dan pada paha kanan timbul kelainan kulit serupa. Dalam 6 bulan terakhir penderita mengeluh batuk-batuk kering, demain, mudah lelah dan tidak nafsu makan. Pada pemeriksaan fisik tampak penderita sakit dengan tubuh yang kurus. Terdapat pembesaran kelenjar getah bening regional pada lipat paha kanan. Alat-alat dalam tidak menunjukkan kelainan dan suhu normal. Pada pemeriksaan kulit di punggung kaki kanan didapatkan jaringan hiperkeratosis berukuran $8 \times 3 \mathrm{~cm}$, merah kecoklatan, dengan erosi, pus, darah, krusta, skuama. Juga didapati jaringan hiperkeratosis berukuran $5 x 5 \mathrm{~cm}$ dengan krusta dan skuama sedikit proksimal dari lesi pertama. Pada paha kanan bagian anterior terdapat jaringan hiperkeratosis berukuran $12 \times 5 \mathrm{~cm}$, serpiginosa, dengan erosi, pus, darah, krusta dan skuama. Pada diaskopi tidak dijumpai apple jelly-like appearance. Pemeriksaan laboratorium menunjukkan peningkatan laju endap darah yaitu $86 \mathrm{~mm} / j a \mathrm{~m}$ dan tes fungsi hati dalam batas normal. Pada pemeriksaan foto toraks didapatkan gambaran tuberkulosis paru bilateral disertai hasil positif pada pemeriksaan basil tahan asam dalam sputum. Tes tuberkulin dengan PPD 5 TU memberi hasil positif kuat. Hasil kultur jamur dan mikrobakterium negatif. Hasil pemeriksaan histopatologik tidak bertentangan dengan tuberkulosis kutis verukosa. Pengobatan dengan obat antituberkulosis yang terdiri atas rifampisin $450 \mathrm{mg} / \mathrm{hari}$, pirazinamid $1000 \mathrm{mg} / \mathrm{hari}$, dan isoniazid $300 \mathrm{mg} / \mathrm{hari}$ menunjukkan perbaikan klinis setelah 3 minggu. Setelah itu pasien tidak datang kembali.
\end{abstract}

\begin{abstract}
A rare case of tuberculosis verrucosa cutis with bilateral pulmonary tuberculosis in a 28 year-old Indonesian male is reported. He has been affected by this disease for 16 years. The lesion began as a slow growing, non pruritic, rough, painless, warty lesion, at the dorsal aspect of his right foot. In the last 2 years, the lesion has thickened, and he noted a warty lesion on his right upper thigh. In the last 6 months he suffered from dry cough, fever, general malaise, and anorexia. Physical examination revealed an afebrile, chronically ill, lean individual, with normal functions. Enlarged regional lymph nodes of the right groin was found. Cutaneous examination showed a firm, slightly red-brown, hyperkeratotic plaque of $5 \times 5 \mathrm{~cm}$ with crusts and scales proximal to the first lesion. On the anterior aspect of the right uppear thigh, there was a serpigineous, hyperkeraatotic plaque $12 \times 5 \mathrm{~cm}$ in size, with erosions, pus, blood, crusts, and scales. An apple jelly-like appearance was not present on diascopic examination. Significant laboratory findings were and elevated blood sedimentation rate of $86 \mathrm{~mm} / \mathrm{h}$ and normal liver function tests. Chest $x$-rays revealed bilateral pulmonary tuberculosis and acid fast bacilli were found in the sputum. The tuberculin test of PPD 5 TU was strongly positive. Tissue cultures of biopsy specimens for either fungi or mycobacteria were negative. Histopathologic examination was sugestive of tuberculosis verrucosa cutis. The patient was given $450 \mathrm{mg}$ rifampicin, $1000 \mathrm{mg}$ pyrazinamide, and $300 \mathrm{mg}$ isoniazid daily. After 3 weeks of therapy, the skin lesion was almost healed. The patient did not show up for a follow-up.
\end{abstract}

Keywords : Tuberculosis verrucosa cutis, Bilateral pulmonary tuberculosis, Antituberculous drugs.

\section{INTRODUCTION}

Tuberculosis verrucosa cutis is a verrucous form of skin tuberculosis in previously infected and sensitized individuals due to an exogenous infection of Mycobacterium tuberculosis or Mycobacterium bovis. It is an inoculation tuberculosis occuring in persons with previous contact to Mycobacterium tuberculosis and thus have acquired a certain degree of immunity and sen- sitivity. ${ }^{1,2,3}$ The tuberculin test is therefore usually positive with hyperergic reaction.

The inoculation usually occurs at sites of minor wounds or abrasions. ${ }^{1,2}$ Occasionally, the inoculation can occur by the patient's sputum. In low socioeconomic areas, children can become infected by playing and sitting on the ground contaminated with tuberculous sputum. ${ }^{1,3}$

Department of Dermato-Venereology, Faculty of Medicine, University of Indonesia/Dr. Cipto Mangunkusumo Hospital, Jakarta, Indonesia 
Tuberculosis verrucosa cutis usually occurs on the hands, often on the radial border of the dorsum, and on the fingers. In children, the predilection sites are the lower extremities, which are most liable to be traumatized. ${ }^{1}$

The lesion is asymptomatic and starts as a small papule or papulopustule with a purple inflammatory halo. It becomes hyperkeratotic and warty, with slow growing development of a verrucous plaque. The consistency is usually firm, but the center can be soft; pus and keratinous material can be expressed from the fissures. There is a serpigineous spreading or peripheral expansion with cicatrix on the central lesion. ${ }^{4}$ The plaques tend to be single, but can be multiple. Lymph nodes are usually not affected, however enlargement of regional lymph nodes can occur after secondary bacterial infection. ${ }^{1,2}$

\section{CASE REPORT}

A 28 year-old Indonesian man came to the Department of Dermatovenereology of Dr. Cipto Mangunkusumo Hospital, Jakarta, on November 16, 1992

\section{History}

At the age of 12, he noted a slow growth of a non pruritic, rough, and painless warty lesion on the dorsal aspect of the right foot. He did not recall any trauma. He was treated at a medical center on several occasions without any success. In the last 2 years, the growth has thickened and he discovered another rough, warty lesion on his right thigh. Six months earlier, he suffered

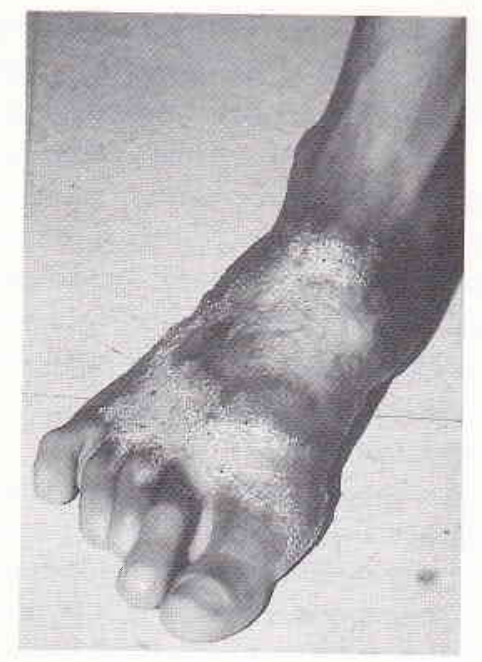

Figure 1. Two hyperkeratotic plaques on the dorsum of the right foot. from a dry cough, fever, general malaise, and anorexia. He was not aware of any tubercular contacts and has never been treated for this ailment.

\section{General conditions}

Physical examination revealed a chronically ill, lean individual, with a blood pressure of $120 / 70 \mathrm{mmHg}$, a respiration rate of $20 /$ minute, and a pulse rate of 80 / minute. The patient was afebril with normal functions. No organomegaly or palpable masses were found. There were an enlargement of the regional lymph nodes of the right groin, which was elastic, mobile, and painful.

\section{Cutaneous examination}

The lesion was firm, slightly red-brown, hyperkeratotic plaque of 8 by $3 \mathrm{~cm}$ in size, with erosions, pus, blood, crusts, and scales on the dorsum of the right foot (Figure 1). Near this lesion, was another hyperkeratotic plaque of 5 by $5 \mathrm{~cm}$ in size, with crusts and scales (Figure 2). On the anterior aspect of the upper thigh, there was a serpigineous, hyperkeratotic plaque of 12 by $5 \mathrm{~cm}$, with erosions, pus, blood, crusts, and scales. No apple jelly-like appearance was present on diascopic examination.

\section{Laboratory findings}

Significant laboratory findings were an elevated blood sedimentation rate of $86 / \mathrm{h}$ and acid fast bacilli were found in the sputum. Other laboratory findings within normal limits.

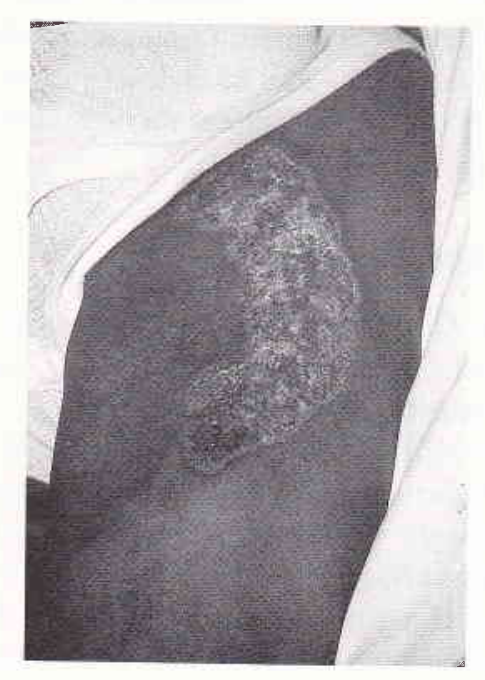

Figure 2. A serpigineons hyperkeratotic plaque on the anterior part of the right upper thigh. 


\section{Chest x-ray}

Bilateral pulmonary tuberculosis with no pleural involvement. Thoracic and lumbal vertebrae showed no abnormalities.

\section{Microbiologic examination}

Tissue culture of biopsy specimen for fungi, Mycobacterium tuberculosis, and atypical mycobacterium were all negative.

\section{Histopathologic examination}

Skin biopsy of all lesions revealed hyperkeratosis, acanthosis of the epidermis with Langhans cells, chronic inflammatory infiltrates, with some epitheloid cells in the dermis (Figure 3 and 4).

\section{Tuberculin test}

Tuberculin skin test with Purified Proteins Derivative 5 TU showed an erythematous induration with a diameter of $20 \times 20 \mathrm{~mm}$.

\section{Therapy}

On first admission, the patient was given oral clindamycin $4 \times 150 \mathrm{mg} /$ day and topical potasium permanganate $1 / 5000$ dressing for one week to treat secondary infection. Antituberculous triple-drug therapy of isoniazid $300 \mathrm{mg} /$ day, rifampicin $450 \mathrm{mg} /$ day, and pyrazinamide 2 x $500 \mathrm{mg} /$ day, with vitamin B6 $30 \mathrm{mg} /$ day, was started on November 28,1992 . The patient came in for a follow-up on Desember 21, 1992, 3 weeks after the start of the treatment, feeling much better and had returned to work. The skin lesion was almost clear (Figure 5 and 6). He did not show up for a subsequent follow-up.

\section{DISCUSSION}

In the Dr. Cipto Mangunkusumo Hospital, tuberculosis verrucosa cutis ranks second, after scrofuloderma, among skin tuberkulosis $(13 \%){ }^{4}$

The differential diagnosis for this patient were lupus vulgaris and chromomycosis. Lupus vulgaris is an extremely chronic and progressive form of skin tuberculosis occuring in individuals with a high degree of tuberculin sensitivity. It originates from a tuberculous condition, or a clinically inapparent tuberculous focus elsewhere in the body, by hematogenous, lymphatic, or contiguous spread. The lesions are usually solitary, but two or more sites may be involved simul- taneously, and in patients with pulmonary tuberculosis, multiple foci may develop. In about $90 \%$ of the patients, the head and neck are involved, although lesions involving the extremities can occur occasionally. ${ }^{1}$ The characteristic lesion is a reddish-brown plaque with deeply embedded peripheral nodules about $1 \mathrm{~mm}$ in size and yellowish (apple jelly) in color. If these nodules are pressed with a glass slide (diascopic examination), they show as a sharphy marginated yellow brown macules. ${ }^{3}$ In our patient, the plaques were hyperkeratotic, with one lesion having a serpigineous spread without an apple jelly appearance on diascopy.

Chromomycosis is a chronic cutaneous and subcutaneous infection of the skin, caused by the species Phialophora, Cladosporium, or Fonsecaea, which forms a wart-like lesion on the skin. It usually begins with a nodule that ulcerates and gradually spreads, forming a large mass on the skin surface. ${ }^{7}$ Progression is slow, and the general health remains good. ${ }^{8}$ The lesions are painless. ${ }^{8}$ These differences are produced by the environment, for example, workers working without shoes or protective clothing on their lower extremities are more likely to suffer trauma on their feet and legs. ${ }^{1}$ On culture, all species produce similiar heaped-up dark colonies with short aerial hyphae, producing a grey, green or brown, velvety surface resembling a mouse pelt. The various causal agents can be differentiated microscopically. ${ }^{3}$ Tissue culture of biopsy specimen from this patient was negative for fungi. Although skin cultures for Mycobacterium tuberculosis or atypical mycobacteria were negative, our patient's sputum was positive for $M$. tuberculosis. Djuanda reported that mycobacterium culture was important in confirming the etiology, but only found positive results in $21,7 \%$ of the cases. ${ }^{4}$

Histologic examination of tuberculosis verrucosa cutis shows hyperkeratosis, papillomatosis, and acanthosis. An acute inflammatory infiltrate can be observed under the epidermis. Tuberculoid structures with a moderate amount of necrosis are usually present in the middermis. Tubercle bacilli, are more numerous when compared to lupus vulgaris. ${ }^{10}$ In chromomycosis, clusters of brown, thick-walled, septated fungal cells can be seen. ${ }^{8}$ Histopathologic examination of biopsy specimen of our patient was suggestive of tuberculosis verrucosa cutis.

Stokes et al. regarded tuberculosis verrucosa cutis as a hyperergic reaction, which gives a positive skin reaction with highly diluted tuberculin $(1: 1,000,000)$. On the other hand, lupus vulgaris is a hyperergic or normergic reaction, which gives a positive reaction with moderatelly diluted tuberculin $(1: 100,000)$. Other reaction are hypoergic reaction, with no reaction given a slightly dilated tuberculin (1:1000 or more), and 


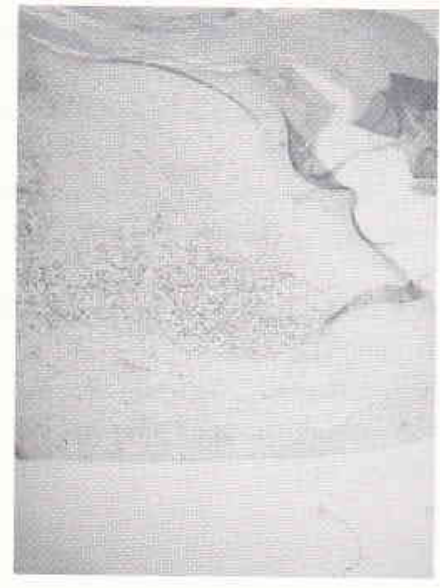

Figure3. Skin biopsy from a distal part of dorsum pedis revealed hyperkeratosis, acanthosis with Langhans cells, chronic inflammatory infiltrates, and some epitheloid cells in the dermis.

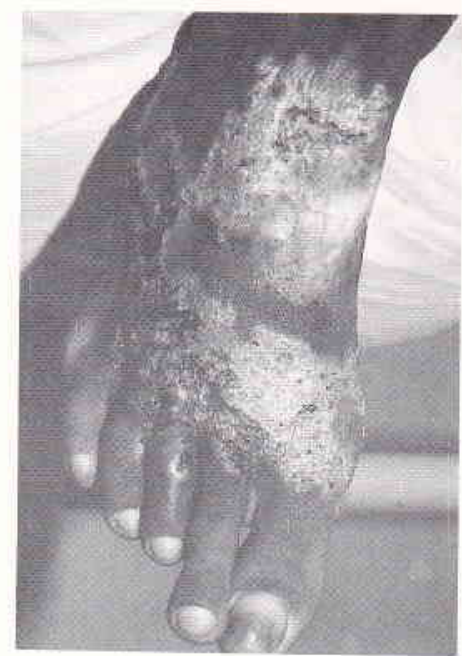

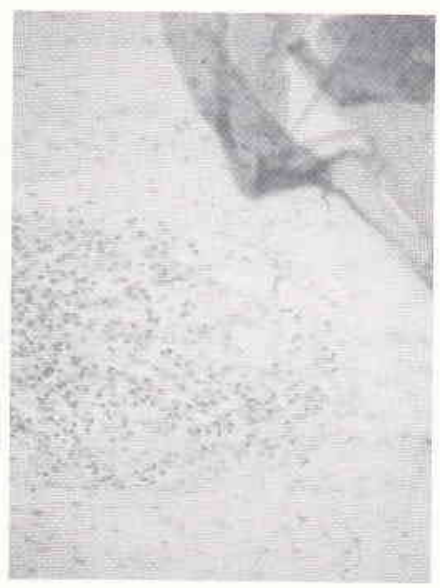

Figure 4. Figure 3 from close up.

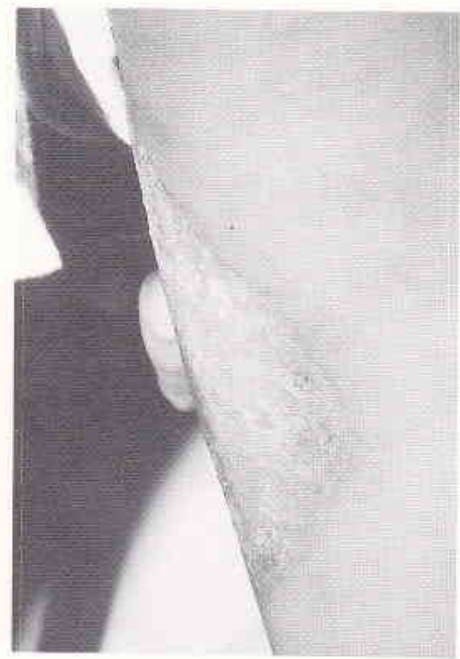

Figure 5 and 6. After 3 weeks of therapy, all lesions either on the dorsum pedis or on the upper thigh showing improvement.

anergic reaction. ${ }^{4}$ Tuberculin skin test (PPD 5 TU) in our patient was strongly positive with a diameter of 20 x $20 \mathrm{~mm}$ erythematous induration. This confirmed a hyperergic reaction.

The patient was treated with isoniazid $300 \mathrm{mg} /$ day, rifampicin $450 \mathrm{mg} / \mathrm{day}$, and pyrazinamide $2 \times 500$ $\mathrm{mg} /$ day. These drugs have potent bactericidal effects, therefore rapid improvements were noted.

Lymph nodes are not affected in tuberculosis verrucosa cutis. The enlargement of the regional lymph nodes of the right groin found in this patient was probably due to secondary infection. It responded well to antibiotics given one week.

\section{CONCLUSIONS}

A rare case of tuberculosis verrucosa cutis with bilateral pulmonary tuberculosis in a 28 year old Indonesian male is reported. The skin disease improved after treatment with a combination of isoniazid $300 \mathrm{mg} / \mathrm{day}$, rifampicin $450 \mathrm{mg} /$ day, and pyrazinamide $2 \times 500$ $\mathrm{mg} /$ day for 3 weeks.

\section{REFERENCES}

1. Wolff K, Tappeiner G. Myobacterial disease : Tuberculosis and atypical Mycobacterial infections. In : Dermatology in 
General Medicine, 3 rd ed. New York : Mc Graw Hill, 1987; 2153-80.

2. Braun-Falco O, Plewig G, Wolff HH, Winkelmann RK. Tubercolisis of the skin, 3 rd ed. Berlin : Springer Verlag, $1990 ; 459-60$.

3. Moschella SL. Disease of the mononuclear phagocytic system. In : Dermatology, vol 1, 2 nd ed. Philadelphia : WB Sauders, 1985; 921-46.

4. Djuanda A. Tuberkulosis kutis. In : Ilmu Penyakit Kulit dan Kelamin. Edisi kedua. Jakarta : Fakultas Kedokteran Universitas Indonesia, 1993; 52-60.

5. Utz JP, Shadomy HJ. Deep fungal infection. In : Dermatology in general medicine, 3 rd ed. new York : Mc Graw Hill, $1987 ; 2248-71$.
6. Lanfas G, Fisher BK, Contreras M. Tuberculous ulcer of the skin. J Am Acad Dermatol. 1988; 19: 1067-72.

7. Wortman PD. Pulmonary and cutaneous tuberculosis. J Am Acad Dermatol. 1992; 27: 459-60.

8. Allen HB, Rippon JW. Subcutaneous and systemic fungal infection. In : Dermatology, 2 nd ed. Philadelphia: WB Saunders, 1985;1: 774-87.

9. Marcoval J, Servitje O, Moreno A. Lupus vulgaris. J Am Acad Dermatol. 1991; 26: 404-7.

10. Lever WF, Schaumburg-Lever G. Bacterial disease. In : Histopathology of the skin. 7 th ed. Philadelphia : J.B. Lippincott company, 1990; 326-33. 